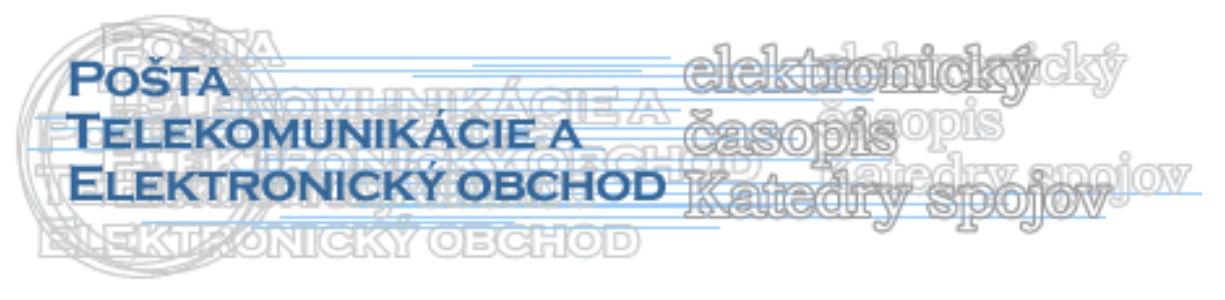

\title{
KNOWLEDGE MANAGEMENT AND ITS SIGNIFICATION FOR ORGANIZATION SUCCESS
}

\author{
Milan Kubiček ${ }^{1}$
}

\section{Introduction}

Knowledge management is the hottest subject of the day but what is this activity called knowledge management? And why is it so important to each and every one of us? If you ask the average management pundit what are today's biggest corporate hot buttons, the chances are they'll say Knowledge Management and intellectual capital.

The civilization turning-point that we are witnessing is connected with the appearance of the New Economy, an economy based on knowledge, which is becoming a strategic resource on all levels of management. At present it is not the material capital, but the intellectual capital that is of crucial significance for the development of an organization and the key factor for its success. [3]

Today, organizations are evolving in an external environment characterized by globalization, rapid technological change, and increasing competition. The establishment of global financial and consumer markets and the need to reduce the time to provide high-quality products and services place significant pressure on organizations to acquire a competitive edge. In achieving competitiveness, „knowledge has become more important for organizations than financial resources, market position, technology, or any other company asset" [4]

Today's economy is defined as an economy based on knowledge - the Knowledge Economy. Knowledge and competence are becoming the main factors of competitive advantage for the companies working in contemporary economic realities and that is why knowledge management is developong into an essential business process. Companies are faced with the challenge of learning how to function under the conditions of a knowledge economy.[3]

\section{Data, information, knowledge and wisdom}

Before attempting to address the question of knowledge management, it's probably appropriate to develop some perspective regarding this stuff called knowledge, which there seems to be such a desire to manage, really is. Consider this observation made by Neil Fleming as a basis for thought relating to the following diagram. The idea is that information, knowledge, and wisdom are more than simply collections. Rather, the whole represents more than the sum of its parts and has a synergy of its own. [2]

\footnotetext{
${ }^{1}$ Ing. Milan Kubiček, Žilinská univerzita v Žiline, Fakulta prevádzky a ekonomiky dopravy a spojov, Katedra spojov, Univerzitná 1, 01026 Žilina, tel.: 041/513 3145, e-mail: Milan.Kubicek@fpedas.uniza.sk,
} 


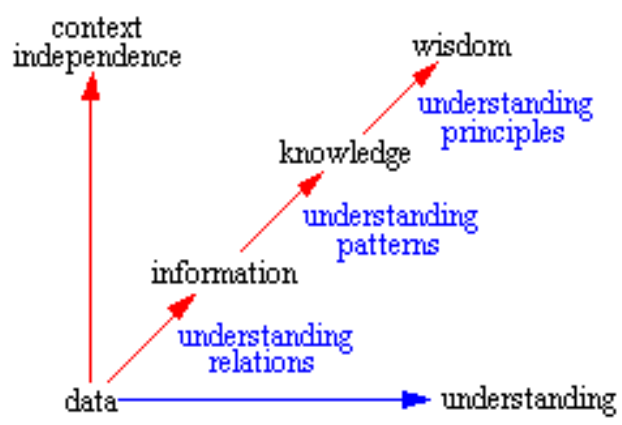

Figure 1: Data/information/knowledge/wisdom [2]

Data - information, often in the form of facts or figures obtained from experiments or surveys, used as a basis for making calculations or drawing conclusions

Information - the collected facts and data about a particular subject

Knowledge - all the information, facts, truths, and principles learned throughout time

Wisdom - accumulated knowledge of life or in a particular sphere of activity that has been gained through experience [6]

In traditional perceptions of the role of knowledge in business organizations, tacit knowledge is often viewed as the real key to getting things done and creating new value. Not explicit knowledge. Thus we often encounter an emphasis on the "learning organization" and other approaches that stress internalization of information (through experience and action) and generation of new knowledge through managed interaction.[9]

At Knowledge Praxis, we define knowledge management as a business activity with two primary aspects:

- Treating the knowledge component of business activities as an explicit concern of business reflected in strategy, policy, and practice at all levels of the organization.

- Making a direct connection between an organization's intellectual assets - both explicit and tacit — and positive business results.

In practice, knowledge management often encompasses identifying and mapping intellectual assets within the organization, generating new knowledge for competitive advantage within the organization, making vast amounts of corporate information accessible, sharing of best practices, and technology that enables all of the above - including groupware and intranets. Knowledge management is hard to define precisely and simply.[9]

There are many problems associated with identifying these knowledge assets and being able to use them and manage them in an efficient and cost-effective manner. Enterprises need:

- to have an enterprise-wide vocabulary to ensure that the knowledge is correctly understood;

- $\quad$ to be able to identify, model and explicitly represent their knowledge;

- to share and re-use their knowledge among differing applications for various types of users; this implies being able to share existing knowledge sources and also future ones;

- $\quad$ to create a culture that encourages knowledge sharing. [7] 


\section{Tacit and Explicit Knowledge}

In the area of knowledge management, a large part of knowledge is not explicit but tacit. Tacit knowledge is characterized by the fact that it is personal, context specific, and therefore hard to formalize and communicate. Explicit, on the other hand, is the knowledge that is transmittable through any systematic language. Human beings acquire knowledge by actively creating and organizing their own experiences. Thus, explicit knowledge represents only the tip of the iceberg of the entire body of knowledge.

In addition, Nonaka and Takeuchi defined their dynamic model, called knowledge conversion process, on the assumption that human knowledge is created and expanded through social interaction between tacit and explicit knowledge.

\section{Knowledge Conversion Process}

Effective KM requires a continuous knowledge conversion process. According to Nonaka and Takeuchi, it represents a social process between individuals and not confined within an individual. Four different modes of knowledge conversion have been postulated (Figure 2):

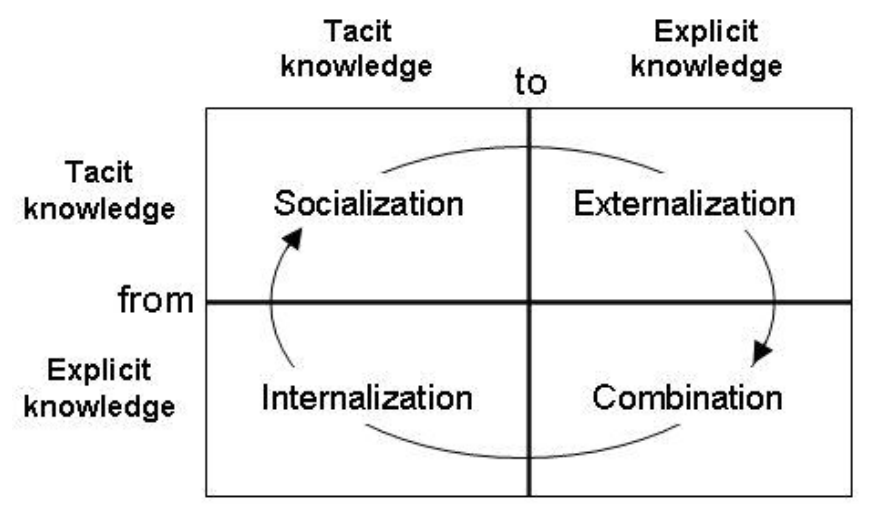

Figure 2 - The knowledge conversion processes in a knowledge creating organization [8]

Externalization (tacit to explicit) is the process of conversion of tacit into explicit knowledge, for example the translation of a clinical trial result into a recommendation for clinical practice. Combination (explicit to explicit) is the process of enriching the available explicit knowledge to produce new bodies of knowledge, for example combining medical and organizational knowledge into a decision support system.

Internalization (explicit to tacit) is the process of individual learning by repeatedly executing an activity applying some type of explicit knowledge, and absorbing the relationship between actions and results as new personal tacit knowledge.

Socialization (tacit to tacit) is the process of learning by sharing experiences that creates tacit knowledge as shared mental models and professional skills (e.g. apprentices learning process, or expert consensus achievement during medical meetings). [8]

\section{Conclusion}

$\mathrm{KM}$ is the process through which organizations generate value from their intellectual and knowledge-based assets. The goal of KM is to simultaneously manage data, information, and explicit knowledge while leveraging what people know (tacit knowledge) through a combination of technology and management practices. 
Intellectual capital and knowledge are crucial significance for the development of an organization and the key factor for its success. They become more important for organisations than other company asset.

\section{References}

[1] BRABECK, R., ŠTOFKOVÁ, K.: Strategisches Management im postindustriellen Zeitalter $=$ Wissensmanagement durch Information und Komunikation. In: Pošta, telekomunikácie a elektronický obchod III/2007, Žilinská univerzita v Žiline, PEDaS, ISSN 1336-8281

[2] Fleming, N.: Coping with a Revolution: Will the Internet Change Learning?, Lincoln University, Canterbury, New Zealand

[3] Guzlecka, A.B, Kurowska, A.D.: Knowledge management in activity of polish postal operator, $7^{\text {th }}$ International Scientific Conference POSTPOINT 2007, Žilina, September $12^{\text {th }}-14^{\text {th }}, 2007$

[4] Schwandt, D.R., Marquardt, M.J.: Organizational learning: from world-class theories to global best practices, Boca Raton 2000

[5] ŠTOFKOVÁ, J. a kol.: Manažment podniku, EDIS Žilina: Žilinská univerzita v Žiline, 2007, ISBN 978-80-8070-713-2

[6] otec.uoregon.edu

[7] www.aiai.ed.ac.uk

[8] www.hcklab.org

[9] www.media-access.com

Príspevok bol publikovaný v rámci projektu VEGA 2009-2011 „Metódy a techniky strategického manažmentu ako nástroj zvyšovania efektívnosti podniku“ č. 1/0757/09 